\title{
Synthesis and Biological Activities of 3-Alkyl-5-substituted 1,2,4-Triazole Derivatives
}

\author{
N. U. SIDDIQUI*, MOHD. ASLAM and RAJESH KUMAR \\ Department of Chemistry, G.F. (P.G.) College, Shahjahanpur (U.P.)-242001, India \\ rajagni83@gmail.com
}

Received 8 September 2012 / Accepted 29 September 2012

\begin{abstract}
Starting from the ester (methyl/ethyl) with hydrazine hydrate, a variety of new compounds 3-alkyl-5-(3'5'dimethyl-1- $H$-pyrazole-1'-yl)-1,2,4,-triazole (5a \& 5b); 3-alkyl-5-( $N$-pyrazolidine)amino-1,2,4-triazole (6a \& $\mathbf{6 b})$ and 2-alkyl-4-mercapto (1,2,4)-triazole (3,4-b) 1,3,4-triazole (7a \& $7 \mathbf{b})$ have been synthesized. All proposed structures were supported by IR, ${ }^{1} \mathrm{H}-\mathrm{NMR},{ }^{13} \mathrm{C}$ NMR and elemental analysis. These newly synthesized compounds (5a \& 5b-7a \& $\mathbf{7 b}$ ) have been screened for their antibacterial activity on E. coli, P. aeruginosa, S. aureus and S. pyrogenes and antifungal activity on C. albicans, A. niger and A. clavatus.
\end{abstract}

Keywords: Alkyl-substituted-1,2,4-triazoles, Antimicrobial activity, Synthesis

\section{Introduction}

In recent years one of the major advancement of medical science is the discovery of new chemicals which are against various microbes. Many of these chemicals are used as medicine in treatment of infectious diseases. Nitrogenous heterocycles are of special interest because they constitute an important class of natural and non-natural products, many of which exhibit useful biological activities. The heterocyclic derivatives may permit the development of novel therapies for the treatment of epilepsy, pain and other neurodegenerative disorders ${ }^{1}$. Azoles are the prominent type of compounds used for this purpose. 1,2,4,-Triazole and its derivatives are an important class of nitrogenous heterocyclic compounds which has been shown to possess a wide range of pharmacological properties such as antifungal ${ }^{2,3}$, antibacterial ${ }^{4,5}$, antimalarial $^{6}$, antiinflammatory, anticonvulsant, antidepressant, antiviral and antitumor activities $^{7-21}$. Therefore, 1,2,4-triazole derivatives have attracted considerable attention during the last few decades $22-25$. In the present work we have synthesized some novel alkyl substituted derivatives of 1,2,4-triazole and evaluated their antimicrobial activities.

\section{Experimental}

The proposed compounds were synthesized in many steps, melting points were determined in open capillary method, purity of the compounds was checked on silica gel T.L.C. plate and compounds were analysed with the help of IR spectra, ${ }^{1} \mathrm{H}$ NMR $\&{ }^{13} \mathrm{C}$ NMR. 
Following methods are involved for the synthesis of 3-alkyl-5-substituted 1,2,4-triazole:

\section{Synthesis of acid hydrazide}

This compound was prepared by refluxing the ester (methyl/ethyl) with hydrazine.

$$
\begin{gathered}
\mathrm{R}-\mathrm{COOMe}+\mathrm{NH}_{2}-\mathrm{NH}_{2} \longrightarrow \mathrm{R}-\mathrm{CO}-\mathrm{NH}-\mathrm{NH}_{2} \\
\mathrm{R}=\mathrm{CH}_{3}(1 \mathrm{a}) ; \mathrm{C}_{2} \mathrm{H}_{5}(1 \mathrm{~b})
\end{gathered}
$$

$1.0 \mathrm{~mL}$ of Hydrazine hydrate was taken in a conical flask fitted with a short reflux condenser; $1.0 \mathrm{~mL}$ of ester (methyl/ethyl) was added drop wise and heated the mixture gently under reflux for 15 minute. Absolute ethanol was added through the condenser to produce a clear solution. Again the content was refluxed for further 2-3 hour. The solution was kept for some time to settle and distilled off the excess of solvent, filtered and dried the crystals of the acid hydrazine in air. Analysis of compound (1a) found $\mathrm{C} \%=32.33, \mathrm{H} \%=8.20, \mathrm{~N} \%=37.75$, calculated for $\mathrm{C}_{2} \mathrm{H}_{6} \mathrm{~N}_{2} \mathrm{O}, \mathrm{C} \%=32.43, \mathrm{~N} \%=37.81, \mathrm{H} \%=8.16$, analysis of compound $(\mathbf{1 b})$ found $\mathrm{C} \%=40.73$, $\mathrm{N} \%=31.71, \mathrm{H} \%=9.05$ and calculated for $\mathrm{C}_{3} \mathrm{H}_{8} \mathrm{~N}_{2} \mathrm{O}, \mathrm{C} \%=40.83, \mathrm{~N} \%=31.81, \mathrm{H} \%=9.10$.

\section{Synthesis of alkanoyl thiosemicarbazide}

This compound was prepared by refluxing the compounds (1a \& 1b) with potassium thiocynate under acidic condition.

$$
\mathrm{R}-\mathrm{CO}-\mathrm{NH}-\mathrm{NH}_{2} \underset{\mathrm{R}=\mathrm{CH}_{3}(2 \mathrm{a}), \mathrm{C}_{2} \mathrm{H}_{5}(2 \mathrm{~b})}{\longrightarrow} \mathrm{RCONH}-\mathrm{NH}-\mathrm{CSNH}_{2}
$$

$7.4 \mathrm{~g}$ Compound (1a \& b) was taken in a conical flask fitted with a short reflux condenser, $9.7 \mathrm{~g}$ solution of potassium thiocynate in ethanol was added drop wise. The reaction mixture was refluxed for 6 hours. The solution was kept for few hours to settle down and the excess solvent was distilled off, filtered and dried the crystals in air. Analysis of compound (2a) found $\mathrm{C} \%=27.52, \mathrm{~N} \%=31.45, \mathrm{H} \%=5.18, \mathrm{~S} \% 24.51$, calculated for $\mathrm{C}_{3} \mathrm{H}_{7} \mathrm{~N}_{3} \mathrm{OS}, \mathrm{C} \%=27.69, \mathrm{~N} \%=31.55, \mathrm{H} \%=5.38, \mathrm{~S} \% 24.61$ and analysis of compound (2b) found $\mathrm{C} \%=32.65, \mathrm{~N} \%=28.47, \mathrm{H} \%=6.00 \mathrm{~S} \% 21.65 \mathrm{O} \% 10.77$ and calculated for $\mathrm{C}_{4} \mathrm{H}_{9} \mathrm{~N}_{3} \mathrm{OS}$, $\mathrm{C} \%=32.65, \mathrm{~N} \%=28.57, \mathrm{H} \%=6.12 \mathrm{~S} \% 21.76 \mathrm{O} \% 10.88$.

\section{Synthesis of 5-mercapto-3-alkyl-1,2,4-triazole}

This compound was obtained by cyclization with compound (2a \& $\mathbf{b})$ in presence of sodium hydroxide.

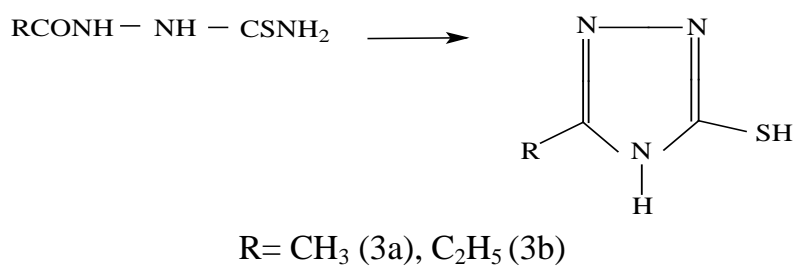

$1.0 \mathrm{~g}$ Compound ( $2 \mathbf{a} \& \mathbf{b}$ ) was taken in a conical flask fitted with a short reflux condenser, $8 \%$ solution of sodium hydroxide $(100 \mathrm{~mL})$ added drop wise with constant stirring for $4 \mathrm{~h}$. The reaction was cooled at room temperature and acidified with dilute acetic acid. The separated product was filtered and washed with water and crystallized from aqueous methanol, as shiny crystal. Analysis of compound (3a) found $\mathrm{C} \%=31.26, \mathrm{~N} \%=34.42, \mathrm{H} \%=4.28$, S\%27.41, calculated for $\mathrm{C}_{3} \mathrm{H}_{5} \mathrm{~N}_{3} \mathrm{O}, \mathrm{C} \%=31.30, \mathrm{~N} \%=34.55, \mathrm{H} \%=4.34, \mathrm{~S} \% 27.61$, analysis of compound (3b) found $\mathrm{C} \%=37.12, \mathrm{~N} \%=32.50, \mathrm{H} \%=5.35 \mathrm{~S} \% 24.56$ and calculated for $\mathrm{C}_{4} \mathrm{H}_{7} \mathrm{~N}_{3} \mathrm{~S}, \mathrm{C} \%=37.20, \mathrm{~N} \%=32.57, \mathrm{H} \%=5.42 \mathrm{~S} \% 24.76$. 


\section{Synthesis of 5-hydrazino-3-alkyl-1,2,4-triazole (4)}

This compound was prepared by refluxing the compound (3a\&b) with hydrazine hydrate in ethanolic medium.<smiles>[R]c1nnc(S)[nH]1</smiles>

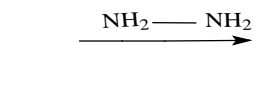<smiles>[R]c1nnc(NN)[nH]1</smiles>

$\mathrm{R}=\mathrm{CH}_{3}(4 \mathrm{a}), \mathrm{C}_{2} \mathrm{H}_{5}(4 \mathrm{~b})$

Methyl (1.03 g)/ethyl (1.15 g) compound (4a \& b) was taken in a conical flask fitted with a short reflux condenser, hydrazine hydrate $0.5 \mathrm{~mL}$ in ethanol added drop wise. The reaction mixture was refluxed for 3-4 hours. The solution was kept for some time to settle and distilled off the excess solvent. The solid product was filtered, washed and dried in air. Analysis of compound (4a) found $\mathrm{C} \%=32.36, \mathrm{~N} \%=69.95, \mathrm{H} \%=6.31$, calculated for $\mathrm{C}_{3} \mathrm{H}_{7} \mathrm{~N}_{5}$, $\mathrm{C} \%=32.43, \mathrm{~N} \%=63.00, \mathrm{H} \%=6.38$, analysis of compound $(\mathbf{4 b})$ found $\mathrm{C} \%=38.35, \mathrm{~N} \%=55.80$, $\mathrm{H} \%=7.12$ calculated for $\mathrm{C}_{4} \mathrm{H}_{9} \mathrm{~N}_{5}, \mathrm{C} \%=38.45, \mathrm{~N} \%=56.00, \mathrm{H} \%=7.21$.

\section{Synthesis of 3-alkyl-5-(3',5-dimethyl-1-H-pyrazole-1-'yl)-1,2,4-triazole}

This is compound was prepared by refluxing the compound (4a \& b) with acetyl acetone in ethanolic medium.<smiles>[R]c1nnc(NN)[nH]1</smiles>

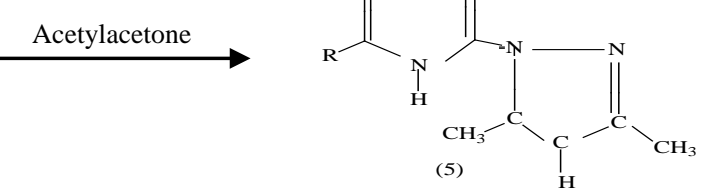

$\mathrm{R}=\mathrm{CH}_{3}(5 \mathrm{a}), \mathrm{C}_{2} \mathrm{H}_{5}(5 \mathrm{~b})$

Methyl (1.13 g)/ethyl (1.27 g) compound (4a \& 4b) was taken in a conical flask fitted with a short reflux condenser, ethanol $(10 \mathrm{~mL})$ and $1.0 \mathrm{~mL}$ acetyl acetone was added drop wise in 15 minute. The reaction mixture was refluxed for 4-5 hours. After refluxing the solution was kept for some time to settle and distilled off the excess solvent. The solid product was filtered, washed and dried in air. Analysis of compound (5a) found $\mathrm{C} \%=54.18$, $\mathrm{N} \%=39.44, \mathrm{H} \%=6.19$, calculated for $\mathrm{C}_{8} \mathrm{H}_{11} \mathrm{~N}_{5}, \mathrm{C} \%=54.23$, N\%=39.54, $\mathrm{H} \%=6.28, .10{ }^{1} \mathrm{H}-$ NMR $\delta \quad 2.55-2.90\left(9 \mathrm{H}, 3 \mathrm{xCH}_{3}\right), 5.1(1 \mathrm{H}, \mathrm{CH}),{ }^{13} \mathrm{C}-\mathrm{NMR} 147(\mathrm{C}), 103(\mathrm{CH}), 11.3-19.3\left(\mathrm{CH}_{3}\right)$, analysis of compound (5b) found $\mathrm{C} \%=56.48, \mathrm{~N} \%=36,58, \mathrm{H} \%=6.75$ and calculated for $\mathrm{C}_{9} \mathrm{H}_{13} \mathrm{~N}_{5}, \mathrm{C} \%=56.54, \mathrm{~N} \%=36,62, \mathrm{H} \%=6.85{ }^{1} \mathrm{H}$ NMR $\delta 2.57-2.88\left(6 \mathrm{H}, 2 \mathrm{xCH}_{3}\right), 1.26(3 \mathrm{H}$, $\left.\mathrm{CH}_{3}\right), 2.58\left(2 \mathrm{H}, \mathrm{CH}_{3}\right), 5.2(1 \mathrm{H}, \mathrm{CH}){ }^{13} \mathrm{C}$ NMR 147(C),103(CH),9.3-18.9 $\left(\mathrm{CH}_{3}\right)$.

\section{Synthesis of 3-alkyl-5-(N-pyrazolidine)-amino-1,2,4-triazole}

This compound was prepared by refluxing the compound (4a \& b) with tetrahydrofuron in ethanolic medium.<smiles>[R]c1nnc(NN)[nH]1</smiles>

Tetrahydrofuran

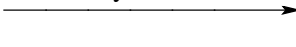

$\mathrm{R}=\mathrm{CH}_{3}(6 \mathrm{a}), \mathrm{C}_{2} \mathrm{H}_{5}(6 \mathrm{~b})$<smiles>[R]c1nnc(NN2CCCC2)[nH]1</smiles> 
Methyl (1.13 g)/ethyl (1.27 g) compound (4a \& 4b) was taken in a conical flask fitted with a short reflux condenser, ethanol $(10 \mathrm{~mL})$ and $0.63 \mathrm{~mL}$ tetrahyrdofuron was added drop wise in 15 minute. The reaction mixture was refluxed for 4-5 hours. After refluxing the solution was kept for some time to settle and distilled off the excess solvent. The solid product was filtered, washed and dried in air. Shiny crystals are formed. Analysis of compound (6a) found $\mathrm{C} \%=50.22, \mathrm{~N} \%=41.71, \mathrm{H} \%=7.68$, calculated for $\mathrm{C}_{7} \mathrm{H}_{13} \mathrm{~N}_{5}, \mathrm{C} \%=50.29$, $\mathrm{N} \%=41.91, \mathrm{H} \%=7.78,{ }^{1} \mathrm{H}-\mathrm{NMR} \delta 2.38\left(3 \mathrm{H}, \mathrm{CH}_{3}\right), 2.8-1.67\left(8 \mathrm{H}, 4 \mathrm{x} \mathrm{CH}_{2}\right),{ }^{13} \mathrm{C}-\mathrm{NMR} 154(\mathrm{C})$, 38.9-53.3 $\left(\mathrm{CH}_{2}\right), 14.6\left(\mathrm{CH}_{3}\right)$, analysis of compound $(\mathbf{6 b})$ found $\mathrm{C} \%=52.92, \mathrm{~N} \%=36.54$, $\mathrm{H} \%=8.19$, and calculated for $\mathrm{C}_{8} \mathrm{H}_{15} \mathrm{~N}_{5}, \mathrm{C} \%=53.00, \mathrm{~N} \%=36.62, \mathrm{H} \%=8.28{ }^{1} \mathrm{H}$ NMR $\delta$ 1.25(3H,CH $\mathrm{CH}_{3}$, 2.81-1.66 (10H,5x CH$),{ }^{13} \mathrm{C}$ NMR 154 (C),8.-54.1 $\left(\mathrm{CH}_{2}\right), 15.8\left(\mathrm{CH}_{3}\right)$.

Synthesis of 2-alkyl-4-mercapto $(1,2,4)$-triazole $(3,4-b)$ 1,3,4-triazole

This compound was prepared by refluxing the compound $(\mathbf{4 a} \& \mathbf{b})$ with carbon disulphide in the presence of ethanol and sodium hydroxide.<smiles>[R]c1nnc(NN)[nH]1</smiles>

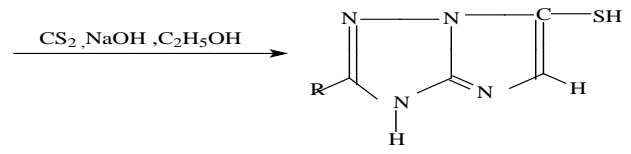

$\mathrm{R}=\mathrm{CH}_{3}(7 \mathrm{a}), \mathrm{C}_{2} \mathrm{H}_{5}(7 \mathrm{~b})$

Methyl(1.13 g)/ethyl(1.27 g) compound (4a \& $\mathbf{4 b}$ ) was taken in a conical flask fitted with a short reflux condenser, $1.52 \mathrm{~mL}$ carbon disulphide and mixture of sodium hydroxide and ethanol was added drop wise in 15 minute. The reaction mixture was refluxed in water bath at $80{ }^{0} \mathrm{C}$ for 10 hours. After refluxing the solution was kept for some time to cool to room temperature. The solid product was filtered, washed with water, neutralized by dilute acetic acid and dried in air. Analysis of compound (7a) found $\mathrm{C} \%=30.88$, N\%=45.12, $\mathrm{H} \%=3.18$, S\%20.54, calculated for $\mathrm{C}_{4} \mathrm{H}_{5} \mathrm{~N}_{5} \mathrm{~S}, \mathrm{C} \%=30.99, \mathrm{~N} \%=45.19, \mathrm{H} \%=3.22, \mathrm{~S} \% 20.64,{ }^{1} \mathrm{H}-\mathrm{NMR} 0.9\left(3 \mathrm{H}, \mathrm{CH}_{3}\right), 6.1(1 \mathrm{H}, \mathrm{CH})$, analysis of compound (7b) found $\mathrm{C} \%=35.49, \mathrm{~N} \%=41.41, \mathrm{H} \%=4.12$ and calculated for $\mathrm{C}_{5} \mathrm{H}_{7} \mathrm{~N}_{5} \mathrm{~S}$, $\mathrm{C} \%=35.50, \mathrm{~N} \%=41.46, \mathrm{H} \%=4.18{ }^{1} \mathrm{H}$ NMR $\delta 0.9\left(3 \mathrm{H}, \mathrm{CH}_{3}\right), 1.4\left(2 \mathrm{H}, \mathrm{CH}_{2}\right), 5.7(1 \mathrm{H}, \mathrm{CH}){ }^{13} \mathrm{C}$ NMR 164,148,148 (C),108(CH), $29.8(\mathrm{CH}), 11.2\left(\mathrm{CH}_{3}\right)$.

\section{Results and Discussion}

The synthesis of the proposed compounds involves many steps. The ester (methyl/ethyl) was taken as initial reactant to produce acid hydrazide (1a $\& \mathbf{1 b})$ by reacting with hydrazine. This acid hydrazide was then converted to semicarbazide (2a \& 2b) by treatment with potassium thiocynate under acidic condition. This compound (2a \& $\mathbf{2 b}$ ) was then undergone cyclization by refluxing with $\mathrm{NaOH}$ to get triazole (3a \& $\mathbf{3 b}$ ) which on treatment with hydrazine get substituted triazole (4a \& $\mathbf{4 b}$ ). From this substituted triazole (4a \& $\mathbf{4 b}$ ) we obtained three different substituted products $(5 \mathbf{a} \& \mathbf{5 b}, \mathbf{6 a} \& \mathbf{6} \mathbf{b}$ and $\mathbf{7 a} \& \mathbf{7 b})$ by treatment with acetyl acetone, tetrahydrofuron and carbon disulphide respectively. When the solid compound (4a \& 4b) 5-hydrazino-3-alkyl-1,2,4-triazole was refluxed with acetyl acetone (active methylene compound) in the presence of ethanol, it gave 3-alkyl-5-(3',5') dimethylpyrazole 1yl)-1,2,4-triazole compound (5a \& 5b). The compound (6a \& 6b) 3alkyl-5-( $N$-pyrazolidine)-amino-1,2,4-triazole was formed by the refluxing of tetrahydrofuron in ethanolic medium. Again, 5-hydrazino-3-alkyl-1,2,4-triazole compound (4a \& 4b) was treated with carbon disulphide and sodium hydroxide in ethanolic medium to form our final product 2-alkyl-4-mercapto [1,2,4] triazole[3,4-b]1,3,4-triazole compound (7a \& b). All these synthesized compounds were analysed for $\mathrm{C}, \mathrm{N}, \mathrm{H}$ and $\mathrm{S}$ as well as spectroscopic 
studies like ${ }^{1} \mathrm{H}$ NMR and ${ }^{13} \mathrm{C}$ NMR. These results are compatible with the proposed structures of the compounds. These compounds were also evaluated for their antimicrobial activities.

\section{Evaluation of antimicrobial activity}

Antibacterial activity

All newly synthesized compounds (5a to $7 \mathbf{b}$ ) were evaluated for in vitro antibacterial activity against gram positive and gram negative bacterial strains such as Escherichia coli, Pseudomonas aeruginosa, Strophylococcus aureus and Streptococcus pyrogenes at concentration $100 \mu \mathrm{g} / \mathrm{mL}$ by disc diffusion method by using DMSO (dimethylsulphooxide) as solvent control and nutrient agar was employed as culture medium. After 24 hours of incubation at $37{ }^{\circ} \mathrm{C}$, the zone of inhibition was measured in $\mathrm{mm}$. The activity was compared with known antibiotic ciprofloxacin and result was represented in Table 1.

Table 1. Antibacterial activity of compounds $\mathbf{5 a}$ to $\mathbf{7 b}$ in terms of diameter of inhibition zone in $\mathrm{mm}$

\begin{tabular}{ccccc}
\hline Compound code & E. coli & P. aeruginosa & S. aureus & S. pyrogenes \\
\hline $\mathbf{5 a}$ & 12 & 15 & 14 & 18 \\
$\mathbf{5 b}$ & 14 & 17 & 18 & 13 \\
$\mathbf{6 a}$ & 16 & 20 & 19 & 18 \\
$\mathbf{6 b}$ & 13 & 19 & 13 & 16 \\
$\mathbf{7 a}$ & 18 & 13 & 15 & 21 \\
$\mathbf{7 b}$ & 14 & 17 & 14 & 19 \\
Ciprofloxacin & 24 & 23 & 25 & 22 \\
\hline
\end{tabular}

Antifungal activity

The synthesized compounds $\mathbf{5 a}$ to $\mathbf{7 b}$ were tested for antifungal activity against Candida albicanes, Aspergillus niger and Aspergillus clavatus by disc diffusion method at 100 $\mu \mathrm{gm} / \mathrm{mL}$ concentration. The results were expressed in terms of diameter of zone of inhibition in $\mathrm{mm}$. A standard antibiotic nystatin was used as control to compare antifungal activities of synthesized compounds and the results are represented in Table 2.

Table 2. Antifungal activity of compounds $\mathbf{5 a}$ to $\mathbf{7 b}$ in terms of diameter of inhibition zone in $\mathrm{mm}$

\begin{tabular}{cccc}
\hline Compound code & C. albicanes & A. niger & A. clavatus \\
\hline $\mathbf{5 a}$ & 15 & 16 & 14 \\
$\mathbf{5 b}$ & 12 & 16 & 14 \\
$\mathbf{6 a}$ & 18 & 19 & 17 \\
$\mathbf{6 b}$ & 19 & 13 & 15 \\
$\mathbf{7 a}$ & 14 & 17 & 20 \\
$\mathbf{7 b}$ & 16 & 13 & 21 \\
Nystatin & 22 & 24 & 21 \\
\hline
\end{tabular}

\section{Acknowledgement}

This work is a part of Ph.D programs of one the authors. The authors express sincere thanks to Head, Department of Chemistry and to the Principal, G.F. (P.G.) College, Shahjahanpur for providing necessary facilities and valuable guidance for the present work. 


\section{References}

1. Katritzky A R, Vakulenko A V, Gedu R A and Rogers J W, Arkivoc, 2007, 8555-8560.

2. Sharma A, Bhat M K, Aher N G, Pore V S, Mishra N N, Kumar A and Shukla P K, Bioorg Med Chem Lett., 2009, 19(3), 759-763.

3. Sangshetti J N, Nagawade R R and Shinde D B, Bioorg Med Chem Lett., 2009, 19(3), 3564-3567.

4. Reck F, Zhou F, Girardot M, Kem G, Eyermann C.J, Holes J N, Romsay R R and Gorvestock M.B, J Med Chem., 2005, 48, 499-506.

5. Pokroveskaya V, Belakhov V, Hanrichson M, Yaron S and Baasov T, J Med Chem., 2009, 52, 2243-2254.

6. Guantai E M, Ncokazi K, Egan T J, Gut J, Rosenthal P J, Smith P J and Chibale K, Bioorg Med Chem., 2010, 18, 8243-8256.

7. $\quad$ Feinstein R N, Fry R J and Staffeld E F, J Natl Cancer Inst., 1978, 60(5), 1113-1116.

8. Milcent R and Vicrot P, Eur J Med Chem-Chim Ther., 1983, 18, 215.

9. Muhi-Eldeen Z, Nadir M, Aljobory N.R, Husseen F and Stohs S, J Eur J Med Chem., 1991, 26, 237.

10. Holla B.S, Gonsolves R and Shenoy S, II Farmaco, 1998, 53(8-9), 574-578.

11. Ikizler A A, Jhonsson C B, Bekiraan O and Celik C, Acta Pol Pharm Drug Res., 1999, 56, 283.

12. Bhat A R, Bhat G V and Shenoy G G, J Pharm Pharmacol, 2001, 53, 267-272.

13. Ulusoy N, Gursoy A and Otuk G, II Farmaco, 2001, 56, 947.

14. Papakonstatinou-Garoufalias S, Pouli N, Marakos P and Chytyroglou-Ladas A, II Farmaco, 2002, 57(12), 973-977.

15. Srivastav S K, Srivastav S and Srivastva S D, Indian J Chem., 2002, 41B, 2357-2363.

16. Demirbas N, Ugurluglo R and Demirbas A, Bioorg Med Chem., 2002, 10, 3717-3723.

17. Collin X, Sauleau A and Coulon J, Bioorg Med Chem., 2003, 13, 2601-2605.

18. Kahveci B, Bekircan O, Serdar M and Ikizler A A, Indian J Chem., 2003, 42B, 1527.

19. Kucukguzel I, Kucukguzel S G, Rollas S, Otuk S G, Ozdemir O, Bayrok I, Altug T, and Stables J B, II Farmaco, 2004, 59(11), 893-901.

20. Demirbas N, Karaoglu S.A, Demirbas A and Sancak K, Eur J Med Chem., 2004, 39(9), 793-804.

21. Demirbas N and Ugurluglo R, Turk J Chem., 2004, 28, 559-571.

22. Ezabadi I R, Camoutsis C, Zoumpoulakis P, Geronikaki A, Sokovic M, Glamocilija J, and Ciric A, Bioorg Med Chem., 2004, 16, 1150-1161.

23. Lednicer D, Org Chem Drug Synth., 2008, 7.

24. Al-Masoudi I.A, Al-Soud Y A and Al-Salihi N J, Chem Heterocycl Comp., 2006, 42, 1377-1403.

25. Saag M S and Dismukes W E, Anti Microb Agent Chemther, 1988, 32, 1-8. 